Egyptian Journal of Rabbit Science, 27 (1): 109 - 129(2017)

\title{
IMPACT OF MAGNETIC EXTENDER ON SEMEN QUALITY, OXIDATIVE STRESS, BACTERIAL COUNT AND FERTILIZING ABILITY IN RABBITS
}

\author{
M. E. El-Speiy; M.A. El-Sawy; Hedia El-Said Ahmed and K.I. Kamel
}

Rabbits Res. Depart. Anim. Prod. Res. Inst., Agric. Res. Center, Ministry of Agric., Egypt. elsawy1966@Gmail.com

Twenty sexually mature bucks and eighty multiparous does of $V$ line rabbits were used. Semen was collected and evaluated twice weekly and only ejaculates showing advanced sperm motility $\geq 70 \%$ were pooled then used. Three experiments were done, the first, tris base extender was divided into four equal portions then exposed to magnetic forces 0, 5000, 6000 and 7000 gauss for $24 \mathrm{hr}$, after that some physical and chemical structure of extender were examined. The second, pooled semen extended by four experimental group samples, semen characteristics were estimated. Samples of diluted semen were taken at $0,24,48$ and $72 \mathrm{hrs}$ of preservation at $4-6^{\circ} \mathrm{C}$. Total antioxidant capacity (TAC), catalase (CAT) and malonyaldehyde (MAD) were determined. The extended semen samples were examined bacteriologically by culturing on nutrient agar. The third, rabbit does were divided into four equal experimental groups and inseminated with semen samples diluted by extender exposed for magnetic forces 0 , 5000, 6000 and 7000 gauss immediately after magnetic exposure. Kindling rate, litter size and weight at birth were recorded.

Results revealed that physical and chemical properties increased except, $\mathrm{Cl}^{-}$element and organic matter values in extender that exposed to different forces of magnetic fields. Advanced motility was increased but dead, abnormal and acrosomal damage were decreased during 72 hr compared to control group. Levels of TAC and CAT activity enzymes were higher but MAD was lower, compared with control at $72 \mathrm{hr}$. exposure to magnetic fields decreased bacterial and fungi growth colony's in nutrient agar. Kindling rate, litter size and weight at birth were higher than control.

Conclusion: Exposing rabbit semen extender to magnetic forces 5000 or 6000 gauss for $24 \mathrm{hr}$ before dilution improved extender and 
semen characteristics throughout preservation at $5^{\circ} \mathrm{C}$ for $72 \mathrm{hr}$, oxidative status and litter size and weight at birth.

Key words: Rabbits, magnetic extender, semen, fertility.

Artificial insemination (AI) is a reproductive technique that has made possible the effective use of best breeding males, thus greatly improving the genetic quality of breeding herds (Januskauskas and Zilinskas, 2002). Successful outcome of AI is depends on a number of factors including management bulls (Thomas, 2009) and improved the storage technique of domestic animal semen (Roca et al., 2006). This is high practical importance for breeding programs in domestic animals and the technique is also used to maintain the genetic diversity and establishment of gene-banks (Jalme et al., 2003). The mammalian sperm include high levels polyunsaturated fatty acids and is immensely weak to oxidative stress which is made of reactive oxygen species (ROS) (Cassani et al., 2005). Also, it has been speculated that ROS influence sperm physiology (Sanocka and Kurpisz, 2004).

Magnetized water is water that has been passed through a magnetic field. It shows increased permeability into cells and electron-donating characteristics. Several studies have investigated effect of magnetized water on disruption to the hydrogen bonding (Zhou et al., 2000 and Chang and Weng, 2008), weakening the van der Waals bonding between the water works as antibiotic molecules (Krems, 2004) and increasing of electronic donor (Tigrek and Barnes, 2010), high hydrogen-bond, increasing electric conduction and smaller formation of ice crystal, magnetized water have ability on reduction of oxide (Szkatula et al., 2002). Ability of high electronic donor was suggesting a possible removing of free radical, antioxidant. Formation of stabilizing cluster was suggesting a possible making of smaller water clusters, high absorption and permeability into organism cells. Ability of magnetized water on organism cells may be expected to protection of sperm cell membrane on domestic animals. Verma (2011) reported that magnetized water stops the growth of bacteria and works as antibiotic.

Examination of bacteria under strong magnetic fields has become of interest (Wang and Liang, 2009). It has direct effect on bacterial growth (Potenza et al., 2004), or changes the antibiotic resistance to bacterial diseases (Stansell et al., 2001). Exposure microorganism to magnetic fields causes inhibition of growth (Anton et al., 2010). Also, magnetized water has a special characteristic that easy super cooling (Zhou et al., 2014), producing of smaller ice crystals (Woo and Mujumdar, 2010), high electronic donor, increasing of electric conduction and increasing of hexamer structure (Tigrek 
and Barnes, 2010). Water structures can form vary formations from a single molecule to clusters of hundreds of molecules bonded together (Tigrek and Barnes, 2010). Especially, hexamer structure is very stable structure of many other molecule clusters, that theoretical predictions of stabilities of the five lowest energy water hexamer structure (Liu et al., 1996). These attributes can protect against membrane damage and remove ROS in mammalian cells (Lee and Park, 2015).

Therefore, water is very important factor on experiment of liquid preservation and cryopreservation in semen. Thus, this study aims to introduce storage technique improved in rabbit semen extender, antioxidant aspects, bacterial count and fertilization rates that propose preservation of rabbit semen using static magnetic field.

\section{MATERIALS AND METHODS}

The present study was carried out at El-Sabahia Poultry Research Station, Alexandria Governorate, belonging to Animal Production Research Institute, Agricultural Research Center, Egypt.

\section{Animals and housing:}

Twenty sexually mature bucks and eighty multiparous does of V-line rabbits were used. The rabbits were housed in a naturally ventilated building and kept in individual wire galvanized cages $(60 \times 55 \times 40 \mathrm{~cm})$. Animals were kept under similar management and hygienic conditions. The lighting program provided 16 hours of light per day. The averages of temperature and relative humidity during experimental period (from October to December) were $18^{\circ} \mathrm{C}$ and $71 \% \mathrm{RH}$. Feed and fresh water were offered ad libitum. They were allowed to a standard pellet diet containing (18\% crude protein, $2.56 \%$ crude fat and $2500 \mathrm{Kcal} / \mathrm{kg}$-ration DE and $12.5 \%$ crude fiber).

\section{Semen collection and processing:}

Semen was collected by an artificial vagina twice weekly for ten consecutive weeks. Gel plug was removed immediately after collection. Semen ejaculates were individually evaluated microscopically and only ejaculates showing advanced sperm motility $\geq 70 \%$ were pooled and used. Tris-base extender was prepared consisting of $3.028 \mathrm{~g}$ tris (hydroxymethylamino-methane, Germany), $1.5 \mathrm{~g}$ citric acid anhydrous, $1.25 \mathrm{~g}$ glucose in 100 $\mathrm{ml}$ distilled water. The extension was carried out by adding the appropriate volume of the semen slowly to the extender. Extended semen was kept in a 
water bath $\left(37^{\circ}\right)$ at all times to avoid fluctuations in semen temperatures and preservation in refrigerator at $4-6^{\circ} \mathrm{C}$ for 72 hours. The base extender was divided into four equal portions and treated as follows:

\section{First experiment:}

G0: Extender not exposed to magnetic field (control group).

G1: Extender exposed to the magnetic field of approximately 5000 gauss.

G2: Extender exposed to the magnetic field of approximately 6000 gauss.

G3: Extender exposed to the magnetic field of approximately 7000 gauss.

Extender was exposed to magnetic field by a permanent magnet in a compact form using a unit called Aqua Correct (Magnetic water softeners and Conditioners, Blue Goose Sales, 200 S Duane Ct, Post Falls ID 83854, USA). This is coaxial permanent system equipment that produced magnetic field strength as high as 5000, 6000 and 7000 gauss. The function is pure magnetic physical, so the crystal structure of lime scale will change and can easily be removed. The strength of the magnetic was measured by Tesla meter (F.W. Bell / Gauss, Model 5070, USA) at Application Laboratory, City for Scientific Research and Biotechnology and Egypt- Japan University of Science and Technology, Egypt.

Three extender samples were placed at the center of the magnetic field of 3 individual exposure devices simultaneously for 24 hours each. Physical and chemical analysis of extender were carried out to determine $\mathrm{pH}$, conductivity, salinity, boiling point, dissolved oxygen, total hardness, sodium, potassium, calcium, magnesium, chloride, carbonate and organic matter.

\section{Second experiment:}

Pooled semen extended by four experimental group samples the final extension rate was 1 part semen: 3 parts extender. Percentages of motility, dead, abnormal sperms and plasma-membrane were estimated according to Boiti et al., (2005). Samples of diluted semen were taken at 0, 24, 48 and 72 hours of preservation at $4-6^{\circ} \mathrm{C}$. Preserved semen was centrifuged at 3000 r.p.m. for 15 minutes and the supernatant was removed and stored at $-20^{\circ} \mathrm{C}$ until enzymatic assay.

\section{Enzymes assay in diluted semen and bacterial count:}

Total antioxidant capacity (TAC), catalase (CAT) and malonyaldehyde (MAD) were determined according to (Koracevic et al., (2001). All biochemical parameters were analyzed by commercially available kit methods. GNW-Model: SM-721Spectrophotometers, Absorbance Micro 
plate Reader and other laboratory equipment aids were used for biochemical analysis. Moreover, each parameter was done according to the instructions of its kit. The extended semen sample was examined bacteriologically according to (Buxton and Fraser, 1977) by culturing on nutrient agar.

\section{Third experiment:}

All rabbit does were injected with $20 \mu \mathrm{g}$ gonadotropin-releasing hormone analogue (GnRH, Receptal, Intervet Lab) to induce ovulation immediately after insemination as described by Lopez and Alvarino (2000). Rabbit does were divided into four equal experimental groups (20 does / each) and inseminated with semen samples from G0, G1, G2 and G3 (30 x $10^{6}$ fertile sperm $/ 0.5 \mathrm{ml}$ average insemination portion) immediately after magnetic exposure. The insemination procedure was done as described by Adams, (1981). Kindling rate and litter size and weight at birth were recorded according to IRRG, (2005).

\section{Statistical analysis:}

All data were subjected to analysis of variance according to the statistical analysis system (SAS, 2002). The differences among groups means were tested by using Duncan's multiple rang test (Duncan, 1955).

\section{RESULTS AND DISCUSSION}

Data in Table 1 revealed that physical and chemical properties improved except, $\mathrm{Cl}^{-}$element and organic matter values in extender that exposed to different forces of magnetic fields. Improving physical and chemical properties of extender was independent on magnetic forces increase as shown in Table 1. The beneficial effects of magnetic field on physical and chemical properties were in agreement with Molouk and Amna, (2010) who stated that $\mathrm{pH}$ value showed significantly increase with increasing magnetic intensity in static treatments.

Kai and Cheng, (2006) revealed that the electrical conductivity as a function to the solubility and dissolution rate into water of some minerals is found to be significant showing a direct proportional relationship with the increasing $\mathrm{pH}$ values, because more hydroxyl $\left(\mathrm{OH}^{-}\right)$groups are created. These molecules that help reduce the acidity in magnetized water, whereas magnetized water can reach $\mathrm{pH}=7.8$ after exposure to a high magnetic field. The increase in conductivity values due to the exposure of the extenders to magnetic field may be due to the reduction in entropy in extender which is a 
result of strengthening of the hydrogen bonds due to the application of magnetic field. The decreases in entropy caused rearrange the molecules in the samples increasing their electric conductivity (Inaba et al., 2004).

Dontas et al., (2011) mentioned that the main component of semen extender is water. Magnetized water has been better electron donor abilities, high hydrogen-bonding, increased electric conduction, formation of smaller ice crystals, and reduction of oxides $\left(\mathrm{SiO}_{2}, \mathrm{Fe}_{2} \mathrm{O}_{3}, \mathrm{CaO}, \mathrm{MgO}, \mathrm{SO}_{3}, \mathrm{Na}_{2} \mathrm{O}\right.$, $\mathrm{K}_{2} \mathrm{O}, \mathrm{CuO}, \mathrm{Mn}_{2} \mathrm{O}_{3}, \mathrm{ZnO}$ and $\mathrm{CO}_{2}$ ). Cho and Lee, (2005) indicated that surface tension in magnetized water is reduced by $10-12 \%$ whilst its velocity is increased compared with regular water. Therefore, it's penetration into cell wall would be facilitated which can accelerate ordinary diffusion of water that is vital for growth of different organs. Nakagawa et al., (1999) showed that the dissolution of oxygen into water is significantly accelerated in the presence of a magnetic field. Al-Mufarrej et al., (2005) mentioned that water solution passes through magnetic field acquire finer and more homogeneous structures which increases the fluidity, dissolving capability for various constituents like minerals and vitamins and consequently improves the biological activity of solutions, affecting positively the performance of animals.

\section{Semen characteristics :}

Data in Table 2 show the effects of magnetic force on diluted semen characteristics of $\mathrm{V}$-line rabbit during different storage times at $5^{\circ} \mathrm{C}$. The percentage of sperm motility significantly increased while, dead and abnormal sperm and also acrosomal damage were significantly decreased as a result to expose semen extender to different forces of magnetic field compared to control group, except the dead sperm in extender exposed to highest magnetic force in G3. Regardless of extender exposure to magnetic forces the sperm motility was significantly decreased due to the increase of preservation time. The change in the decadence of previous semen parameters due to preservation time had inverse association with exposing the extender to different forces of magnetic fields.

The improve in semen characteristics (Table 2) due to exposure to magnetic forces may be related to the improvement of chemical medium that used for preservation and provide energy for metabolic activities in sperm cell; maintain osmotic pressure and $\mathrm{pH}$ of the medium (Salamon and Maxwell, 2000).

Extender also keeps a check on the contamination of the medium to protect semen from microbial growth. Rabbit semen unlike other species, 
presents a low water permeability coefficient and high activation energy. This low water permeability value is consistent with the need to use cryoprotectents of lower molecular weight and higher permeability (such as DMSO or amides) than glycerol for rabbit sperm cryopreservation (Curry et al., 1995). Dontas et al., (2011) mentioned that the main component of semen extender is water. Magnetized water has been better electron donor abilities, high hydrogen-bonding, increased electric conduction, formation of smaller ice crystals, and reduction of oxides $\left(\mathrm{SiO}_{2}, \mathrm{Fe}_{2} \mathrm{O}_{3}, \mathrm{CaO}, \mathrm{MgO}, \mathrm{SO}_{3}, \mathrm{Na}_{2} \mathrm{O}, \mathrm{K}_{2} \mathrm{O}, \mathrm{CuO}, \mathrm{Mn}_{2} \mathrm{O}_{3}, \mathrm{ZnO}\right.$ and $\mathrm{CO}_{2}$ ). Seo et al., (2013) confirmed that magnetized water could has improving ability of sperm on cryopreservation in Korean native cattle. Faezah et al., (2012) mentioned that the use of magnetic separation as the sperm preparation technique can somehow enhance sperm cryosurvival rate after cryopreservation. Sang and Choon, (2015) pointed out that highly magnetized semen extender could protect the sperm membrane from damage, and improve the ability of rates of in vitro blast cyst development.

\section{Antioxidant assay:}

The total antioxidant capacity, CAT and MAD activities in extended semen with magnetized extender for different storage periods at $5^{\circ} \mathrm{C}$ are given in Table 3. The concentration of TAC and CAT enzymes showed significant increase in diluted semen as a result to exposing their extender to different magnetic forces. On the other hand, the generation of MAD was significantly reduced compared to control group (Table 3) during incubation at $5^{\circ} \mathrm{C}$. Regardless of treatment effect, significant decrease in TAC and CAT values and significant increases in MAD value were observed as affected by incubation time at $5^{\circ} \mathrm{C}$. Our results agreed with Lee and Park, (2015) who mentioned that magnetized extenders have antioxidative effects on the liquid preservation of boar sperm.

Balanced reactive oxygen species (ROS) plays vital role in the chromatin condensation, membrane remodeling and intracellular pathways activation (Pons-Rejraji et al., (2009), however, increased ROS level will damage the cell membrane and disturbs the intracellular pathways. Therefore, supplementation of extender with antioxidants plays a key role in semen extenders and was found to be most effective in various species (Beccaglia et al., 2009).

Nihal et al., (2006) documented that a significant increase of SOD activity when passed magnetic field. Also, Mojca et al., (2008) showed that 
a magnetic treatment (of solutions) raises the reducing ability of the oxidation ability of hydrogen. Bahadır et al., (2016) mentioned that static magnetic field accelerates peroxidation reactions possibly by suppressing SOD and GSH-Px enzymes in the cancerous gastric tissue.

\section{Bacterial count:}

Results indicated that magnetic fields (5000, 6000 and 7000 gauss) had highly effect on bacteria and fungi colony's growth in nutrient agar (Figure 1). A decrease in the number of colony's forming started immediately after exposure to magnetic field on bacteria could be considered as bactericidal.
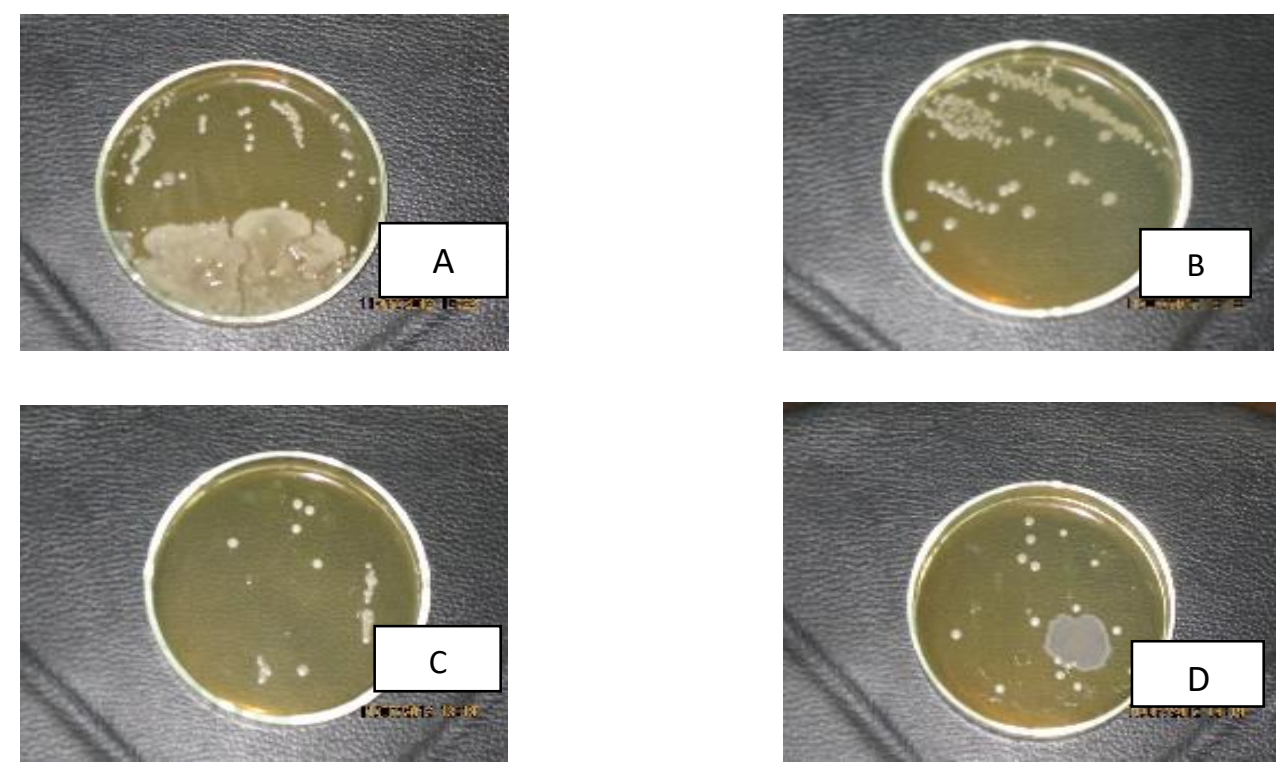

Figure1. Effect of magnetic force on bacteria colony

\section{A: Force without magnetic. \\ C: Force 6000 gauss.}

B: Force 5000 gauss. D: Force 7000 gauss.

Various antibiotic ingredients have been used so far, to keep check on the microbial contamination in extenders. Generally, the fresh semen from the physically fit bull is free from microorganisms. However, during semen collection via artificial vagina, presence of sugar (fructose) in extender and room temperature $\left(20^{\circ} \mathrm{C}\right)$ during processing are the promoting factors for bacterial growth. The most common contaminants are Gram positive bacteria along with E. coli and Salmonella spp (Gadea, 2003). Some other 
Species like Clostridium progenies and Pseudomonas aurogenosa are considered as potential threats to be transferred via cryopreserved semen. The other contagious bacteria include Brucella abortus, Vibrio fetus, Trichomonas fetus, Leptospira pomona, Mycoplasma bovis and Mycobacterium Spp (Michajilov, 1950).

Contamination with bacteria decreases the nutrients available for sperm cells leading to decreased $\mathrm{pH}$ that affects the motility and viability of spermatozoa. Similarly, fungi produce different kinds of endo- and exotoxins that affect the sperm viability during preservation of semen. Semen extender components from animal source should be free from all kinds of microorganisms (Marco et al., 2004). The control of venereal disease along with cryoshock protection, improved the fertility by $15 \%$ (Foote, 2002). Cornel extender was the first standard diluents to have Penicillin G, Streptomycin, and Polymixim-B (Foote and Bratton, 1949) as an antimicrobial agent for several years approved by the National Association of Animal Breeders. This recipe prevented most of the venereal disease and decreased the early embryonic death. Microbial contamination decreased sperm motility, acrosome integrity and $\mathrm{pH}$ of semen (Althouse et al., 2000). Similarly, some of the antibiotics used to exert a severe effect on the sperm cell mitochondria resulting in depression on the progressive motility as mitochondria plays vital role in the tail movements and overall energy required for cellular activities (Ahmad et al., 1987). In harmony with our results, Strasak et al., (2002) noticed the ability of bacteria to form decreased colonies with increasing magnetic field intensity and with increasing time of exposure due to changed chemical properties by magnetic force, the growth of bacterial cells was inhibited as their composition changed. Piatti et al., (2002) reported that, when exposing Serratia marcescens to magnetic force of $80 \pm 20$ gauss lead to the inhibition of its growth. El-Sayed et al., (2006) reported that, the growth of E. coli can be reduced by exposing it to a magnetic field. Fouad et al., (2014) concluded that the cellular membrane of the microorganism had been affected by the magnetic field, also the response increased when the field intensity increased. So the magnetic field effects on bacteria (Staphylococcus aureus) are considered bactericidal, and hence, a change in the number of the cells per $\mathrm{ml}$ or the measured change in the membrane sensitivity to antibiotic demonstrated also the change in the internal structure of the cells. Saeed et al., (2012) reported that a significant increase in the logarithm of the number of Escherichia coli $(\mathrm{CFU} / \mathrm{ml})$ treated with high frequency electromagnetic field and a significant decrease in the 
number of Escherichia coli (CFU/ml) exposed to low-frequency electromagnetic field.

\section{Fertility trial:}

Results of the fertility trial are presented in Table 4. Data showed that exposing semen extender to different magnetic forces caused significant increase in kindling rate, litter size and weight at birth compared to control group. The highest value in the previous data due to magnetic forces effect was shown with 5000 and 6000 gauss. There were no significant differences in bunny weight at birth between control group and both 5000 and 6000 gauss magnetic forces. Exposed semen extender to 7000 gauss magnetic force caused lowest significant bunny weight at birth.

Fertilizing ability of spermatozoa is influenced by combination factors including motility, viability and an ability to undergo capacitating and the acrosome reaction in the female reproductive tract (Martí et al., 2003). Hammadeh et al., (2001) accepted that acrosome function is essential for the fertilizing ability of sperm no matter what it is fresh semen or frozen semen, because acrosomal enzymes allow them to reach the oocyte plasma membrane and damage of the acrosomes has been reported to be associated with a lower fertilizing capacity.

Table 4. Fertility of V-line rabbit does inseminated artificially by semen diluted with magnetic extender with different forces.

\begin{tabular}{|l|c|c|c|c|}
\hline \multirow{2}{*}{ Items } & \multicolumn{4}{|c|}{ Magnetic force (gauss) } \\
\cline { 2 - 5 } & $(\mathrm{G} 0)$ & $(\mathrm{G} 1)$ & $(\mathrm{G} 2)$ & $(\mathrm{G} 3)$ \\
& $\mathbf{0 . 0}$ & $\mathbf{5 0 0 0}$ & $\mathbf{6 0 0 0}$ & $\mathbf{7 0 0 0}$ \\
\hline Mated does (N) & 40 & 40 & 40 & 40 \\
\hline Conceived does (N) & 26 & 32 & 34 & 28 \\
\hline Kindling rate (\%) & $65.3^{\mathrm{c}}$ & $84.7^{\mathrm{a}}$ & $85.0^{\mathrm{a}}$ & $70.0^{\mathrm{b}}$ \\
& $\pm 3.2^{\mathrm{c}}$ & $\pm^{\mathrm{a}} .8$ & \pm 2.7 & \pm 2.9 \\
\hline Litter size at birth & $6.7^{\mathrm{c}}$ & $8.2^{\mathrm{a}}$ & $8.5^{\mathrm{a}}$ & $7.5^{\mathrm{b}}$ \\
& \pm 0.3 & \pm 0.6 & \pm 0.5 & \pm 0.3 \\
\hline Litter weight at birth (g) & $266.7^{\mathrm{c}}$ & $339.3^{\mathrm{a}}$ & $345.3^{\mathrm{a}}$ & $289.8^{\mathrm{b}}$ \\
& $\pm 1.7^{\mathrm{a}}$ & \pm 3.8 & \pm 3.8 & \pm 1.4 \\
\hline Bunny weight at birth (g) & $40.33^{\mathrm{a}}$ & $41.7^{\mathrm{a}}$ & $40.86^{\mathrm{a}}$ & $38.64^{\mathrm{b}}$ \\
& $\pm 1.9^{\mathrm{b}}$ & \pm 3.0 & \pm 3.7 & \pm 3.9 \\
\hline
\end{tabular}

Means within the same row $(\mathrm{a}, \mathrm{b}, \mathrm{c})$ within each parameter bearing different letter superscripts are significantly different $(\mathrm{P} \leq 0.05)$. 
Semen traits or composite indexes better predict the fertilizing capacity of spermatozoa. Quinteiro et al., (2007) developed a composite index using a multivariate regression approach by entering several parameters of rabbit semen (motility, sperm abnormalities and altered acrosomes) which better predicts the fertilizing ability and the prolificacy of semen samples. Jian-hong et al., (2006) mentioned that the ability of fertility of spermatozoa after cryopreservation is an important factor of high-pregnancy rates in mammalian after insemination, and is being associated with the quality of sperm after cryopreservation process.

Marschall et al., (2009) reported magnetized semen extender effect on fertility in vitro fertilization. Sang and Choon, (2015) suggest that highly magnetized semen diluter could improve the ability of rates of in vitro blastocyst development and is beneficial for long liquid preservation of boar semen.

Conclusively, from these results it could be concluded that exposing rabbit semen extender to magnetic forces 5000 or 6000 gauss for $24 \mathrm{hr}$ before dilution improved extender and semen characteristics throughout preservation at $5^{\circ} \mathrm{C}$ for $72 \mathrm{hr}$, oxidative status and litter size and weight at birth.

\section{ACKNOWLEDGEMENT}

The authors are thankful to Prof. Dr. Aboelfotoh Mohammed Abdallah, Department of Agricultural Engineering, Faculty of Agriculture, Zagazig University for reviewing physical part of Magnatic forces design in this work.

\section{REFRENCES}

Adams, C.E. (1981). Artificial insemination in the rabbit: The technique and application to practice. Journal of Applied Rabbit Research, 4:1013.

Ahmad K; Foote RH and Kaproth M. (1987). Antibiotics for bull semen frozen in milk and egg yolk extenders. Jour. Dairy Sci.; 70: 24392443.

Al-Mufarrej, S.; Al-Batshan, H.A.; Shalaby, M.I. and Shafey, T.M. (2005). The effects of magnetically treated water on the performance and immune system of broiler chickens. Inte. Jour. Poultry Sci., 4(2): 96-102.

Althouse, G.C.; Kuster, C.E.; Clark, S.G. and Weisiger, R.M. (2000). Field investigation of bacterial contaminants and their effects on the porcine semen. Theriogenol., 53:1167-1176. 
Anton, L.V.; Haanappel, E. and Marsaud, N. (2010). Exposure to high static or pulsed magnetic fields does not affect cellular processes in the yeast Saccharomyces cerevisiae. Bio-Electro Magnetic., Vol. 31, (1). 28-38.

Bahadır, Ö.; Zahide, E. D.; Süleyman, B. and Ender, H.K. (2016). Effect of static magnetic field on oxidant/antioxidant parameters in cancerous and no cancerous human gastric tissues. Scientifics (Cairo); Hindawi Publishing Corporation Scientifica, Volume 2016, P,1- 4 .

Beccaglia, M.; Anastasi, P.; Chigioni, S. and Luvoni, G.C. (2009). Trislecithin extender supplemented with antioxidant catalase for chilling of canine semen. Reprod. Dom. Anim. 44(2):345-349.

Boiti, C.; Guelfi, G.; Brecchia, G.; Dall, A.C.; Ceccarelli, P.; Maranesi, M.; Mariottini, C.; Zampini, D.; Gobbetti, A. and Zerani, M. (2005). Role of endothelin-1 system in the luteolytic process of pseudopregnant rabbits. Endocrinology, 146: 1293-1300.

Buxton, A. and Fraser, G. (1977). Animal Microbiology. Vol. (1) Blackwell Scientific Publications.

Cassani, P.; Beconi, M.T. and Flaherty, O.C. (2005). Relationship between total superoxide dismutase activity with lipid peroxidation, dynamics and morphological parameters in canine semen. Anim. Reprod. Sci., 86(1):163-173.

Chang, K.T. and Weng, C.I. (2008). An investigation into the structure of aqueous $\mathrm{NaCl}$ electrolyte solutions under magnetic fields. Comput. Mater. Sci., 43(4):1048-1055.

Cho, Y.I. and Lee, S.H. (2005). Reduction in the surface tension of water due to physical water treatment for fouling control in heat exchangers. International Communications in Heat and Mass Transfer; 32:1-9.

Curry, M.R.; Redding, B.J. and Watson, P.F. (1995). Determination of water permeability coefficient and its activation energy for rabbit spermatozoa. Cryobiology, 32: 175-181.

Dontas, I.A.; Lelovas, P.P.; Kourkoulis, S.K.; Aligiannis, N.; Paliogianni, A.; Mitakou, S.; Galanos, A.; Kassi, E.; Mitousoudis, A.; Xanthos, T.T.; Papaioannou, N. and Lyritis, G.P. (2011). Protective effect of Siderites euboea extract on bone mineral density and strength of ovari-ectomized rats. Menopause , 18: 915-922.

Duncan, D.B. (1955). Multiple range and multiple F tests. Biometrics, 11:1-42. 
EL-Sayed, A.G.; Magda, S.H.; Eman, Y.T. and Mona, H.I. (2006). Stimulation and control of $E$. coli by using an extremely low frequency magnetic field. Romanian J. Biophys., 16(4): 283-296.

Faezah, S.S.M., F.M.Y Zuraina, J.H.F. Farah, O. Khairul, N.I. Hilwani, M.I. Iswadi, C.N. Fang. (2012). The effects of magnetic separation on cryopre served bovine spermatozoa motility, viability and cryo-capacitation status. Zygote: page 1-9 C; Cambridge University Press doi: 1017/S0967199412000597.

Foote, R.H. (2002). The history of artificial insemination: Selected notes and notables. Jour. Anim. Sci.; 80: 1-10.

Foote, R.H. and Bratton, R.W. (1949). The fertility of bovine semen cooled with and without the addition of citrate sulfanilamide yolk extender. Jour. Dairy Sci.; 32: 856-861.

Fouad, H.K., Chiman, H.S. and Saleem, S.Q. (2014). Magnetic field effect on growth and antibiotic susceptibility of staphylococcus aureus. Journal of Al-Nahrain University, Vol. 17(3), September, 138-143.

Gadea, J. (2003). Semen extenders used in artificial insemination of swine. Spanish Jour. Agric., 1(2):17- 27.

Hammadeh, M.E.; T. Georg; P. Rosenbaum and W. Shmidt. (2001). Association between freezing agent and acrosome damage of human spermatozoa from subnormal and normal semen. Andrologia, 33: 331-336.

Inaba, H., Saitou, T., Tozaki, K.; Hayashi, H. (2004). Effect of the magnetic field on the melting transition of $\mathrm{H}_{2} \mathrm{O}$ and $\mathrm{D}$ [sub 2] $\mathrm{O}$ measured by a high resolution and supersensitive differential scanning calorimeter. Jour. Appl. Phys., 96(11):6127-6132.

International Rabbit Reproduction Group (IRRG). (2005). Recommendations and guidelines for applied reproduction trials with rabbit does. World Rabbit Sci., 13: 147-164.

Jalme, M.S.; Lecoq, R.; Seigneurin, F.; Blesbois, E. and Plouzeau, E. (2003). Cryopreservation of semen from endangered pheasants: the first step towards a cryobank for endangered avian species. Therio., 59: 875-888.

Januskauskas, A. and Zilinskas, H. (2002). Bull semen evaluation post thaw and relation of semen characteristics to bull's fertility. Vet. Zootec., 17, 29-36. 
Jian-hong H.; Qing, W.L; Gang, L.; Xiao, Y.C.; Hai, Y.; Shu, S.Z. and Li, Q.W. (2006). The cryoprotective effect on frozen-thawed boar semen of egg yolk low density lipoproteins. Asian-Aust. J. Anim. Sci., Vol 19, No. $4: 486-494$.

Kai, T.C. and Cheng, I.W. (2006). The effect of an external magnetic field on the structure of liquid water using molecular dynamics simulation. Journal of Applied Physics, 100: (4): 171-176.

Koracevic, D.G.; V. Djordjevic and V.S. Andrejevic (2001). Method for the measurement of antioxidant activity in human fluids. Jour. Clin. Pathol., 54: 356-361.

Krems, R.V. (2004). Breaking van der Waals molecules with magnetic fields. Phys. Rev. Lett., 93(1):013-201.

Lee, S.H. and Park, C.K. (2015). Antioxidative effects of magnetized extender containing bovine serum albumin on sperm oxidative stress during long-term liquid preservation of boar semen. Biochem. Biophys. Res. Commun., (2):467-472.

Liu, K.; Brown, M.G.; Carter, C.; Saykally, R.J.; Gregory, J.K. and Clary, D.C. (1996). Characterization of a cage form of the water hexamer. Nature , 381(6582):501-503.

Lopez, E.F.J. and Alvarino, J.M.R. (2000). Effects of added caffeine on results following artificial insemination with fresh and refrigerated rabbit semen, Anim. Reprod., 58(1-2): 147-154.

Marco, J.N.F.; Puchades, S.; Moce, E.; Viudes, D.C.M.P.; Vicente, J.S.; Rodriguez, M. (2004). Use of powdered egg yolk vs fresh egg yolk for the cryopreservation of bovine semen. Reprod. Dom. Anim.; 39: 438-841.

Marschall, S.; Boersma, A. and Angelis, M. (2009). Sperm cryopreservation and in vitro fertilization. In: Gene Knockout Protocols. Humana Press, pp. 407-420.

Martí, J.I.; E. Martí; E. Cebrián-Pérez and T. Muiòo Blanco (2003). Survival rate and antioxidant enzyme activity of ram spermatozoa after dilution with different extenders or selection by a dextran swimup procedure. Theriogenology, 60: 1025-1037.

Michajilov, N.N. (1950). The Sperm Dilution In The Milk. Czecho- Slovak Vet. Mag. Jour. Am. Vet. Med. Assoc. 117:337.

Mojca Bo i, Lucija Crepinsek Lipus, and Vanja Kokol (2008). Magnetic field effects on redox potential of reduction and oxidation agents. Croat. Chem. Acta., 81 (3) 413-421. 
Molouk, M.K.A. and Amna, A.N. (2010). The effect of magnetic field on the physical, chemical and microbiological properties of the lake water in Saudi Arabia. Jour. of Volutionary Biology Research, Vol. 2(1) pp. 7-14.

Nakagawa, J.; Hirota, N. and Kitazawa, K. S. (1999). Magnetic Field enhancement of water vaporization. Jour. Appl. Phys., 86: 29232925.

Nihal, B.y.; Kuslu, Z.E. and I. Atak (2006). The effect of magnetic field on the activity of superoxide dismutase. Journal of Cell and Molecular Biology, 5: 57-62.

Piatti E.; Albertini, M.C.; Baffone, W.; Fraternale, D.; Citterio, B.; Piacentini, M.P.; Dacha, M.; Vetrano, F. and Accorsi, A. (2002). Antibacterial effect of magnetic field on Serratia marcescens and related virulence to Hordeum vulgure and Rubs frulicosus callus cell. Comp. Biochem. Physiol. Biochem. Mol. Biol., 132 (2): 359-365.

Pons-Rejraji H.; Sion B.; Saez F.; Brugnon F.; Janny L. and Grizard, G. (2009). Role of reactive oxygen species (ROS) on human spermatozoa and male infertility. Gynecol. Obstet. Fertil.; 37:529-35.

Potenza, L.; Ubaldi, L.; De Sanctis, R.; De Bellis, R.; Cucchiarini, L. and Dacha, M. (2004). Effects of a static magnetic field on cell growth and gene expression in Escherichia coli. Mutat. Res., 561:5362.

Quinteiro-Moreno, A.; Rigaul, T. and Rodríguez-Gil, J.E. (2007). Multivariate cluster analysis regression procedures as tools to identify motile sperm subpopulations in rabbit semen and to predict semen fertility and litter size. Reprod. Dom. Anim., 42: 312-319.

Roca, J.; Vazquez, J.M.; Gil, M.A.; Cuello, C.; Parrilla, I. and Martinez, E.A. (2006). Challenges in pig artificial insemination. Reprod. Domest. Anim., 41(2): 43-53.

Saeed, N.; Asghar, T.; Davoud, K.; Seyyed, Reza Moaddab; Kaveh EbrahimPour and Khorshid Badihi (2012). Study the Effects of High and Low Frequencies Pulsed Square Electromagnetic Fields on the Logarithmic Growth of the E. Coli. Bull. Environ. Pharmacol. Life Sci.; Volume 1 (60: 26-29.

Salamon, S. and Maxwell, W.M.C. (2000). Storage of ram semen. Anim. Reprod. Sci., 62: 77-111. 
Sang, H.L. and Choon K.P. (2015). Effect of magnetized extender on sperm membrane integrity and development of oocytes in vitro fertilized with liquid storage boar semen. Animal Reproduction Science, Vol. (154), pp. 86-94.

Sanocka, D. and Kurpisz, M. (2004). Reactive oxygen species and sperm cells. Reprod. Biol. Endocrinol., 2(12):1-7.

SAS (2002). SAS/STAT User's guide Statistics. SAS institute INC., Cary. NC, USA.

Seo, G.B.; Lee, Y.S.; Lee, K.J.; Yu, H.J.; H.T. Yang; Lee, J.W. and Park, C.K., (2013). Effect of Magnetized Water on Cryopreservation in Bovine Spermatozoa. Food and Agriculture Organization of the United Nation, Vol. 35.

Stansell, M.J.; Winters, W.D.; Doe, R.H. and Dart, B.K. (2001). Increased antibiotic resistance of $E$. coli exposed to static magnetic fields. Bio-Electro-Magnetic, 22(2): 129-137.

Strasak, L.; Vetterl, V. and Smarda, J. (2002). Effects of low-frequency magnetic fields on bacteria Escherichia coli. Bioelectro-Chemistry, 55: 161-164.

Szkatula, A.; Balanda, M. and Kopeć, M. (2002). Magnetic treatment of industrial water. Silica Activation. Eur-Phys Jour. Applied Physics, 18(1): 41-49.

Thomas, H.S. (2009). Managing Bulls for Optimum Production. Hereford World / March P:30-33.

Tigrek, S. and Barnes, F. (2010). Water structures and effects of electric and magnetic fields. In: Non-The Normal Effects and Mechanisms of Interaction between Electromagnetic Fields and Living Matter. Giuliani, Soffritti, Eds and Fidenza editors. Bologna Italy: An ICEMS Monograph, pp. 25-50.

Verma, S.S. (2011). Magnetic water treatment. Chemical Business Journal, January, 13-16.

Wang, X. and Liang, I. (2009). Effects of static magnetic field on magneto some formation and expression of mamA, mms13, mms6 and magA in Magneto spirillum magneticum AMB-1. Biolectromagnetics, 30(4):313-321.

Woo: M. W. and A. S. Mujumdar (2010). Effects of Electric and Magnetic Field on Freezing and Possible Relevance in Freeze Drying. Drying Technology, 28:(4): 433-443. 
Zhou, K.X.; Lu, G.W.; Zhou, Q.C.; Song, J.H.; Jiang, S.T. and Xia, H.R. (2000). Monte Carlo simulation of liquid water on magnetic field. Jour. Appl. Phys. ,88(4):1802-1805.

Zhou, Z.; Zhao, H. and Han, J. (2014). Super cooling and crystallization of water under DC magnetic fields. CIESC Jour., Vol. 63: pp.14051408.

\section{أثر تعريض مخفف السائل المنوى للمجال المغناطيسى على صفات السائل

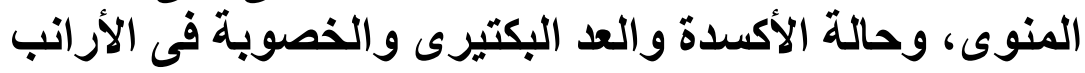

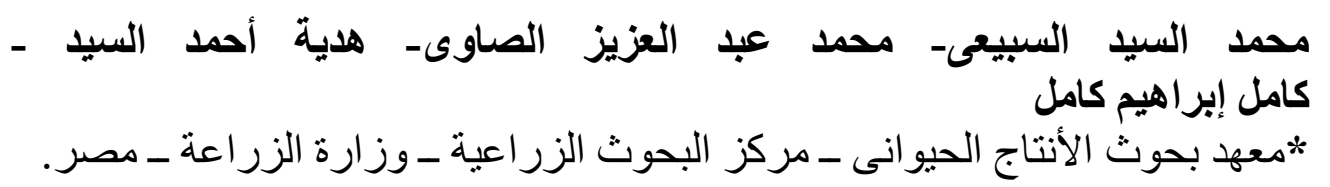

تم إستخدام عدد ·r ذكر أرنب ناضج جنسيا، ، ^ أنتى متعددة الو لادات من خط V-Line،

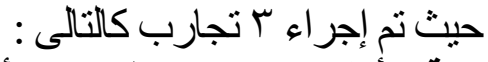

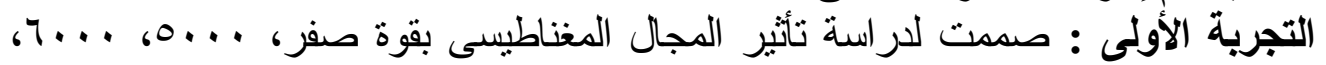

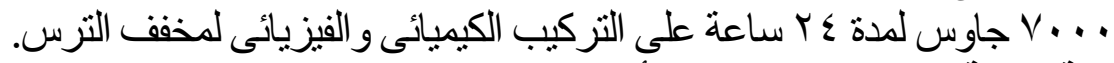

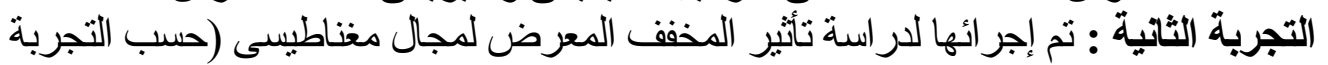

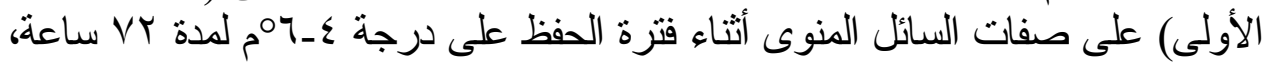
وحالة الأكسدة وكذللك على النموات البكتيرية و الفطرية في بيئة الأجار.

التجربة الثالثة : تم إجرائها لدراسة صفات الخصوبة للأمهات الملقحة إصطناعيا بالسائل المنوى المخفف بمخفق سبق تعريضه لمجال مغناطيسى بقوى مختلفة (حسب التجربة الأولى). وقد أوضحث النتائج مايلى: - دثت زيادة في المكونات الفيزيائية و الكيميائية لمخفف التزس ما عدا عنصر الكلور و المادة العضوية نتيجة التعرض اللمجال المبال المغناطيسى فى كل المجاميع المختبرة.

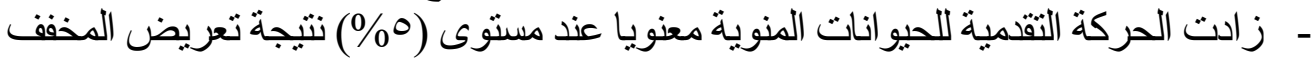
للمجال المغناطيسى. - إنخف معنويا عند مستوى (0\%) نسبة كل من الحيوانات المنوية الميته والمشوهة

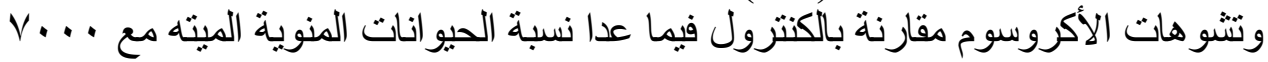
جاوس. 
- إرتفع معنويا على مستوى (0\%) نثاط إنزيمات CAT, TAC فى السائل المنوى المخفف

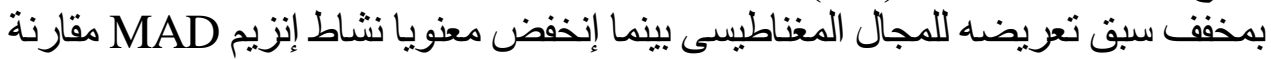

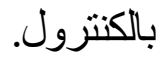
- أظهر التعريض للمجال المغناطيسى تأثير ا خافضا للنموات البكتيرية والفطرية فى بيئة

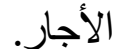

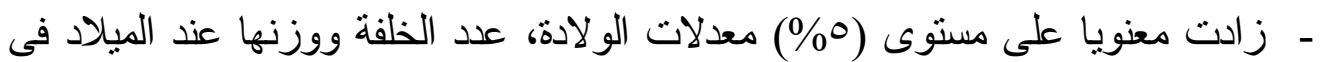

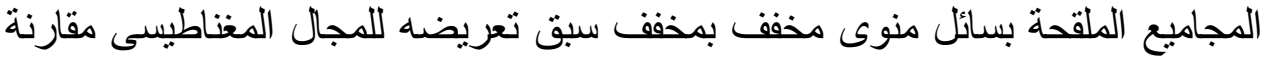

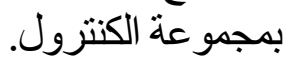
التوصية: تعريض مخفف الترس المستخدم لتخفيف السائل المنوى للأرانب لمدة ؟ ؟ ب ساعة

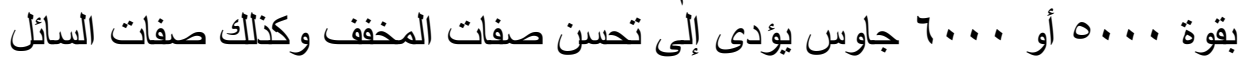

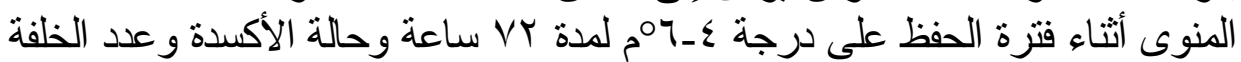

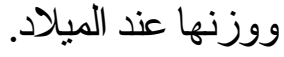

